\title{
Sustainable architectural design: towards climate change mitigation
}

\author{
Milan Sijakovic \\ TTArchitects, London, UK, and \\ Ana Peric \\ Institute for Spatial and Landscape Development, \\ Eidgenossische Technische Hochschule Zurich, Zurich, Switzerland and \\ Faculty of Architecture, University of Belgrade, Belgrade, Serbia
}

\begin{abstract}
Purpose - Excessive amounts of carbon dioxide $\left(\mathrm{CO}_{2}\right)$ undoubtedly lead to climate change, which directly affects both the natural and the built environment. Observing the impact of climate change on the construction industry, this paper examines sustainable architectural design as a tool to mitigate climate change.

Design/methodology/approach - To achieve the previous goal, the authors conduct a comprehensive documentary analysis of three types of sources: (1) scholarly articles in the fields of climate research, sustainable construction, green buildings and sustainable architecture; (2) contemporary global reports on climate change and its impact on the built environment and (3) practitioners' guides explaining practical architectural solutions to the climate crisis.

Findings - The systematic analysis provides three types of results: objectives, strategies and principles of sustainable architectural design aimed at mitigating the effects of climate change. On the one hand, the research results provide a solid basis for further conceptual research into architectural design responsive to the effects of changing climate. On the other hand, the detailed strategies and principles are relevant for urban designers and architects.

Originality/value - Among a range of literature in the field of climate change and its effects on the built environment, a particular value of the paper is in addressing a very local level, i.e. the level of individual building and its immediate surroundings. More specifically, this paper provides concrete design components that help reduce $\mathrm{CO}_{2}$ emissions, finally decreasing the vulnerability index of urban systems.
\end{abstract}

Keywords Climate change, Built environment, Construction industry, Sustainable architecture, Green building, $\mathrm{CO}_{2}$ emission

Paper type Research paper

\section{Introduction}

The Earth's climate has been changing throughout its history. Until now, this has happened mostly due to natural causes. However, as a result of the human activities, causing an increase in the levels of greenhouse gases (GHG) in the atmosphere, the climate is changing beyond its natural variability (Younger et al., 2008; Altomonte, 2008; Wilby, 2007; LCCP, 2002; IPCC, 2019). Human-generated gases derive in part from features of the built environment such as transportation systems and infrastructure, building construction and operation and land-use planning. Through the combustion of fossil fuels and living matter, humans have changed the chemistry of the atmosphere and the entire terrestrial climate system. More significantly, if behavioural patterns remain the same as in the past, human activities will continue to change the composition of the atmosphere, and temperatures and sea levels will continue to rise for many centuries to come.

As both the reasons that accelerate further climate change and the effects of the changing climate are mostly associated with inhabited areas, the climate crisis is essentially urban. First, the causes of climate change stem from urbanization and urban agglomerations: (1) although occupying less than $2 \%$ of the global land area, 4.2 billion people currently live in cities aiming to reach $70 \%$ of global population in 2050 (IPCC, 2014b); (2) $90 \%$ of this urban growth will occur in future megacities (UN DESA, 2019); (3) cities are great energy consumers

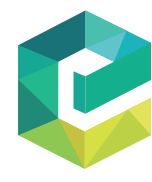

Archnet-IJAR: International Journal of Architectural Research C) Emerald Publishing Limited DOI 10.1108/ARCH-05-2020-0097 
(78\%) and carbon dioxide $\left(\mathrm{CO}_{2}\right)$ emitters $(60 \%)$ due to their density of population, industry and transport network (IPCC, 2014b).

Second, cities worldwide face severe negative consequences of a rapidly transforming climate (IPCC, 2014a). High risk of flooding from rising sea levels, stressed water sources, storms and more intense precipitation events is extremely challenging for cities having in mind that $90 \%$ of global urban areas are coastal. Heat waves, winter cold and extreme weather events are getting more frequent, causing heavy impacts on urban aspects: human health, infrastructures and environments. Due to the changing climate, urban migration has recently become one of the central topics to address in regard to climate issues. Finally, considering the time pressure for limiting global warming to $1.5^{\circ} \mathrm{C}$ until 2030 (IPCC, 2018), effective climate change mitigation and adaptation must be urban at its core.

Key international policies on climate change - the Paris Agreement (UNFCCC, 2015) and the Sendai Framework for Disaster Risk Reduction 2015-2030 (UNISDR, 2015) - commit only national/federal governments as essential for climate action. However, with the 2030 Agenda for Sustainable Development (UN, 2015) and especially the New Urban Agenda (UN, 2017), urban areas are now explicitly addressed as agents and targets in terms of climate change. Correspondingly, UN-Habitat $(2016,2017)$ has reinforced its efforts to empower major urban groups, while C40 and R100 networks also assume cities as leaders in climate action. This action can be implemented through tools linked to the management, planning and design of cities, e.g. collaborative governance arrangements, innovative urban planning mechanisms and responsive urban design instruments, respectively. While both scholarly and professional debate revolves mainly around the recommendations for strengthening local stakeholders and networks (Bulkeley, 2013; Castán Broto, 2017; Hughes et al., 2018; Wolfram et al., 2019) on the one hand and the implementation of nature-based solutions in planning (Marzluff et al., 2008; Glaser et al., 2014; Grove et al., 2015) on the other hand, the third pillar, i.e. improving the performance of buildings as elementary units of any built environment requires special attention too.

Through different decisions about site, landscape surroundings, electricity and water usage, and materials utilized, buildings may either reduce or accelerate the climate change (Younger et al., 2008). More precisely, buildings affect the GHG emissions through various aspects of their design, location, orientation and use, e.g. their relationship to each other and the neighbouring landscape, the material composition and design elements of their interiors and exteriors and the energy and water resources used by their occupants (Younger et al., 2008; IPCC, 2019). Accordingly, different measures for coping with future changes in temperature, relative humidity, levels of precipitation, wind speeds and frequency of extreme weather events have been explored (Lisø, 2001; Wilby, 2007; Souch and Grimmond, 2006; Mills, 2006; Hunt, 2004; Oke, 1987). For example, to reduce risks to human and environmental health and promote the energy-efficient infrastructure and changed patterns of resource consumption, the following strategies have been proposed: improved architectural and urban design; improved operational weather and air quality forecasts for urban areas and designing more energy- and water-efficient settlements and buildings. Among a range of established techniques for countering the effect of rising temperatures in urban areas, the following proved to be particularly efficient: reducing building densities; changing building height, spacing and street orientation to increase shade and reduce insolation receipt; enhancing natural ventilation through a variation of building height and density; achieving effective solar shading using trees and vegetation; use of high-albedo (reflective) building materials; improved building and cooling system design and incorporation of large areas of vegetation and water features within the urban landscape. Such mechanisms equally address the challenges that may appear whilst creating new designs or recycling the existing building stock (Sijakovic and Peric, 2014, 2018; Sijakovic, 2015). 
Despite the fact that the mentioned strategies and techniques all contribute to curbing the changing climate, they are rarely jointly implemented in a comprehensive and coordinated manner (Wilby, 2007; Altomonte, 2008). Accordingly, we need a new approach to architectural design, the one simultaneously addressing the complex requirements of the environment with its finite resources and the needs of contemporary societies and economies, and bringing together environmental responsibility, strategies for mitigation of human impacts and the notion of climate responsiveness (Altomonte, 2008). Following this line of argumentation, we assume the responsive architectural design as a tool to mitigate climate change. From a macro-scale perspective, we aim to define objectives, strategies and principles of sustainable architectural design, while addressing the micro-level, we identify design patterns that help to reduce $\mathrm{CO}_{2}$ emissions, finally decreasing the vulnerability index of urban systems.

The paper is structured as follows. In the first place, the effects of human activity on our environment are analysed, and the sustainable development concept is introduced, focussing primarily on the construction sectors. The link between the construction industry and sustainable development is elucidated, and the stress this industry places on all aspects of sustainable development is analysed. Furthermore, the analysis of the concept of sustainable architectural design is conducted identifying the objectives, strategies and principles aimed at mitigating the effects of climate change.

\section{Environmental change in the Anthropocene}

The year 2000 marked the shift in the urban-rural population ratio. For the first time in world history, urban population exceeded the rural one. This drift of a human population from countryside to cities entails the intensification of urban problems and puts pressure on housing land, water and energy supplies as well as sewage and waste capacity. Thus, as the human species becomes more urbanized, we consume more, waste more and pollute more (Edwards, 2005).

According to Szokolay (2004), coal was the most important energy source since the 18th century, i.e. our industrial civilization has been built on coal. In the early 20th century, the oil production began, and its use has rapidly grown with the introduction of the internal combustion engine as used in cars, trucks, aeroplanes but also in stationary applications. The oil production by regions, as well as total, from 1930 to the middle of this century, is presented in Figure 1. The figure predicts that demand will exceed supply, and that production will decline. This phenomenon is referred to as 'rollover', and such rollovers have already occurred in some regions, e.g. around 1970 for the USA and Canada and in 1986 for the UK and Norway (Szokolay, 2004).

Furthermore, the environment is increasingly stressed by our economic success and population growth (Edwards, 2005). By 2050 it is anticipated that the human race will have four times the environmental impact it had in 2000 (based on a $2 \%$ annual economic growth and a global population of 10 billion). In 1973, the OPEC (Organization of the Petroleum Exporting Countries) oil embargo brought home the realization of the finite nature of our fossil fuel supplies. In the same year, the RIBA (Royal Institute of British Architects) initiated the long life, lose fit, low energy (LL/LF/LE) movement, which states that it would be ecologically beneficial to erect buildings which are designed in a way to remain adaptable for changed uses and which use little energy in their operation (Szokolay, 2004). The "Brundtland report" (WCED, 1987) introduced the term sustainable development as development that meets the needs of the present without compromising the ability of the future generations to meet their own needs. Sustainable development may be based on three principles (GauzinMüller, 2002): 


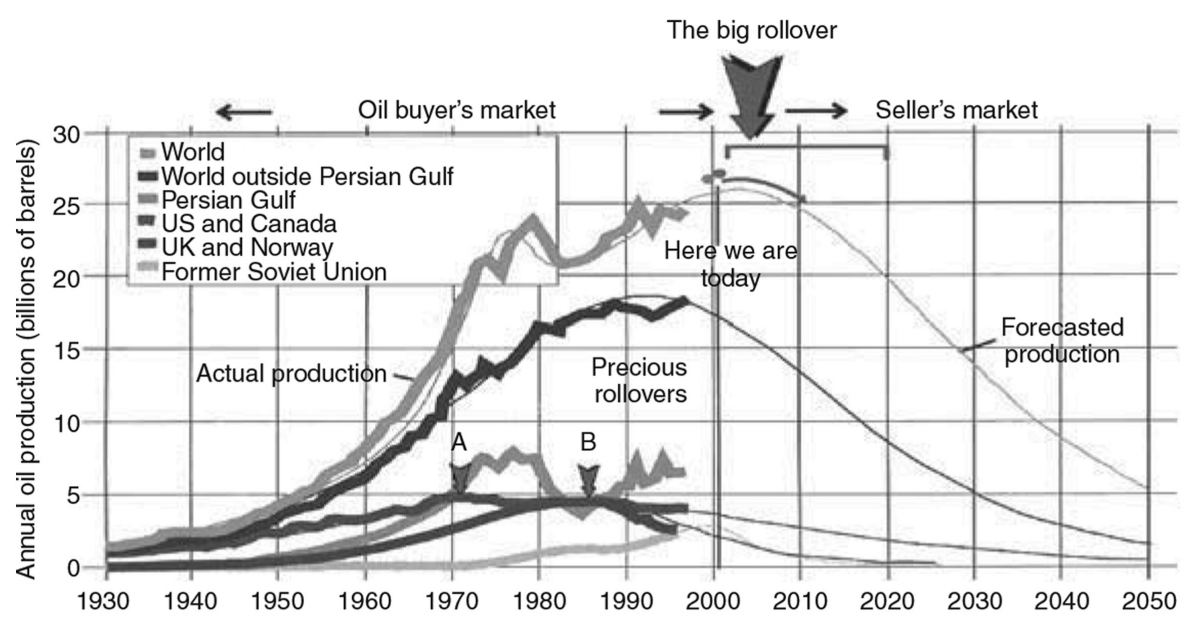

Figure 1.

History and forecast of world (and regional) oil production. $\mathrm{A}=\mathrm{USA}$ and Canada and $\mathrm{B}=\mathrm{UK}$ and Norway

Source(s): Szokolay, 2004

(1) Complete material life cycle assessment;

(2) Development and use of renewable raw materials and energy and

(3) Reduction of the amounts of materials and energy used in the extraction and exploration of natural resources and the recycling or final destination of the residues.

This concept was accepted internationally, being usually divided into three domains: environmental, economic and social. Their brief characteristics are given below (König et al., 2010; Pearce et al., 2007; WACOSS, 2008; Anand and Sen, 1996; EC, 2007):

(1) The ecological dimension of sustainability concerns the preservation of our basis for life and means limiting the stain on our resources to the ecologically acceptable level, which is fixed by the long-term preservation of the stock of natural resources.

(2) Economic sustainability contains three main criteria: consideration of the value of the environment; extension of the time horizon and equity between people and generations. The production and consumption processes should meet ecological requirements and will therefore work as a long-term cost-avoidance strategy.

(3) Social sustainability occurs when the formal and informal processes (systems, structures and relationships) actively support the capacity of current and future generations to create healthy and liveable communities. Therefore, socially sustainable communities are equitable, diverse, connected and democratic and provide a good quality of life. Social sustainability consists of following six dimensions: equity, diversity, interconnected/social cohesions, quality of life, democracy and governance and maturity.

(4) Recently, the cultural dimension of sustainability was introduced referring to the conservation of non-material, cultural values for future generations (Figure 2). Cultural diversity is as essential for the identity of societies as biodiversity is for the nature. 


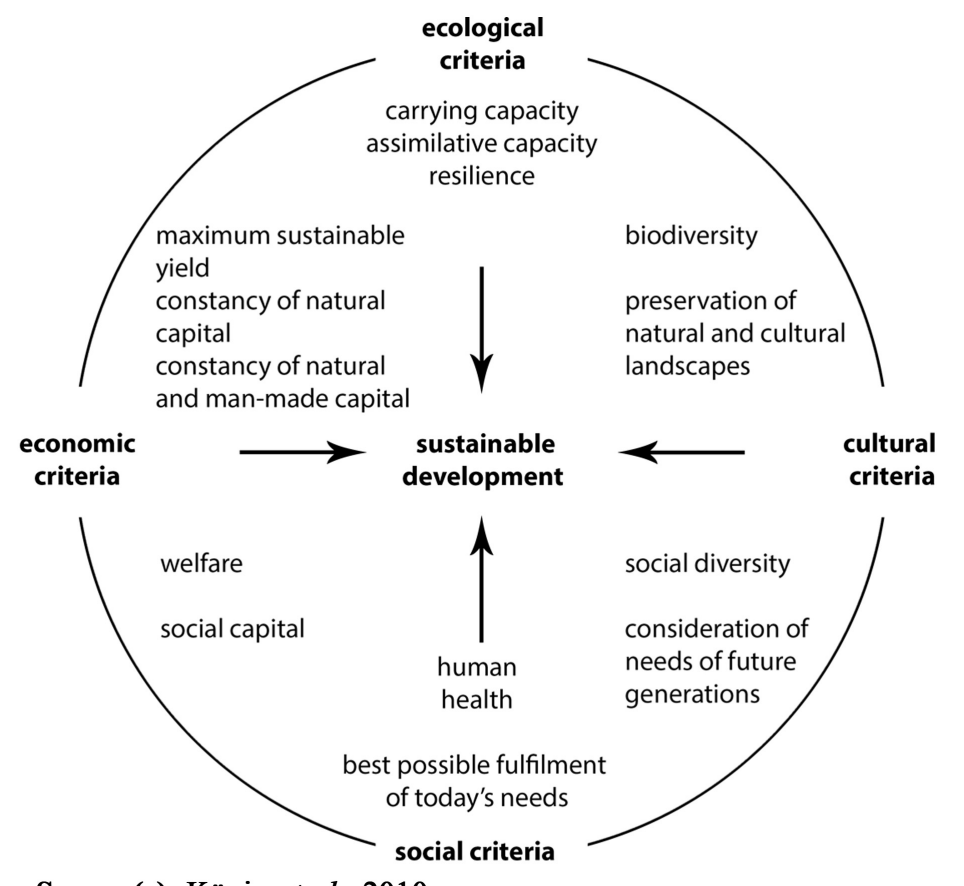

Architectural design towards climate change

Source(s): König et al., 2010

Figure 2. Dimensions of sustainability

The evolution of thought on environmental change, and, more specifically, its effect on the built environment is given in Figure 3.

\section{Sectorial aspects of sustainability: construction industry}

The influence of human activity on numerous subtle changes in the environment over time is becoming increasingly clear, from the bleaching of coral reefs and the polluting of oceans by regular oil spills to the damage of human health caused by harmful processes, materials and buildings (Cepinha et al., 2007; Steffen et al., 2015). Out of all resources consumed across the planet $50 \%$ are used in construction, as shown in Figure 4, which makes it one of the least sustainable industries in the world.

However, contemporary human civilization depends on buildings for its continued shelter and existence even though our planet cannot support the current level of resource consumption (Edwards, 2005). Hence, the topics such as sustainable construction, sustainable architecture, sustainable design and similar come to the fore and have been explored by numerous research bodies and professional organizations (Edwards, 2005; Szokolay, 2004). For example, Foster and Partners defines the sustainable design as the process of creating energy-efficient, healthy and comfortable buildings, flexible in use and designed for long life. The Buildings Service Research and Information Association (BSRIA) refers to sustainable construction as a process of creation and management of healthy buildings based upon resource efficient and ecological principles. The International Union of Architects (IUA) calls for national architectural bodies and associations to begin producing energy and environmental policies. The International Council for Research and Innovation in Building and Construction (CIB) presented the Agenda 21 on Sustainable Construction. This document 


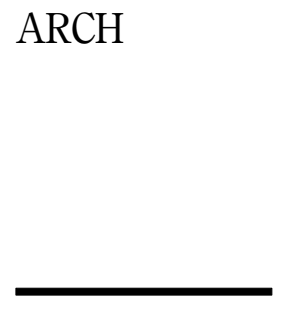

Figure 3.

Major global environmental agreements

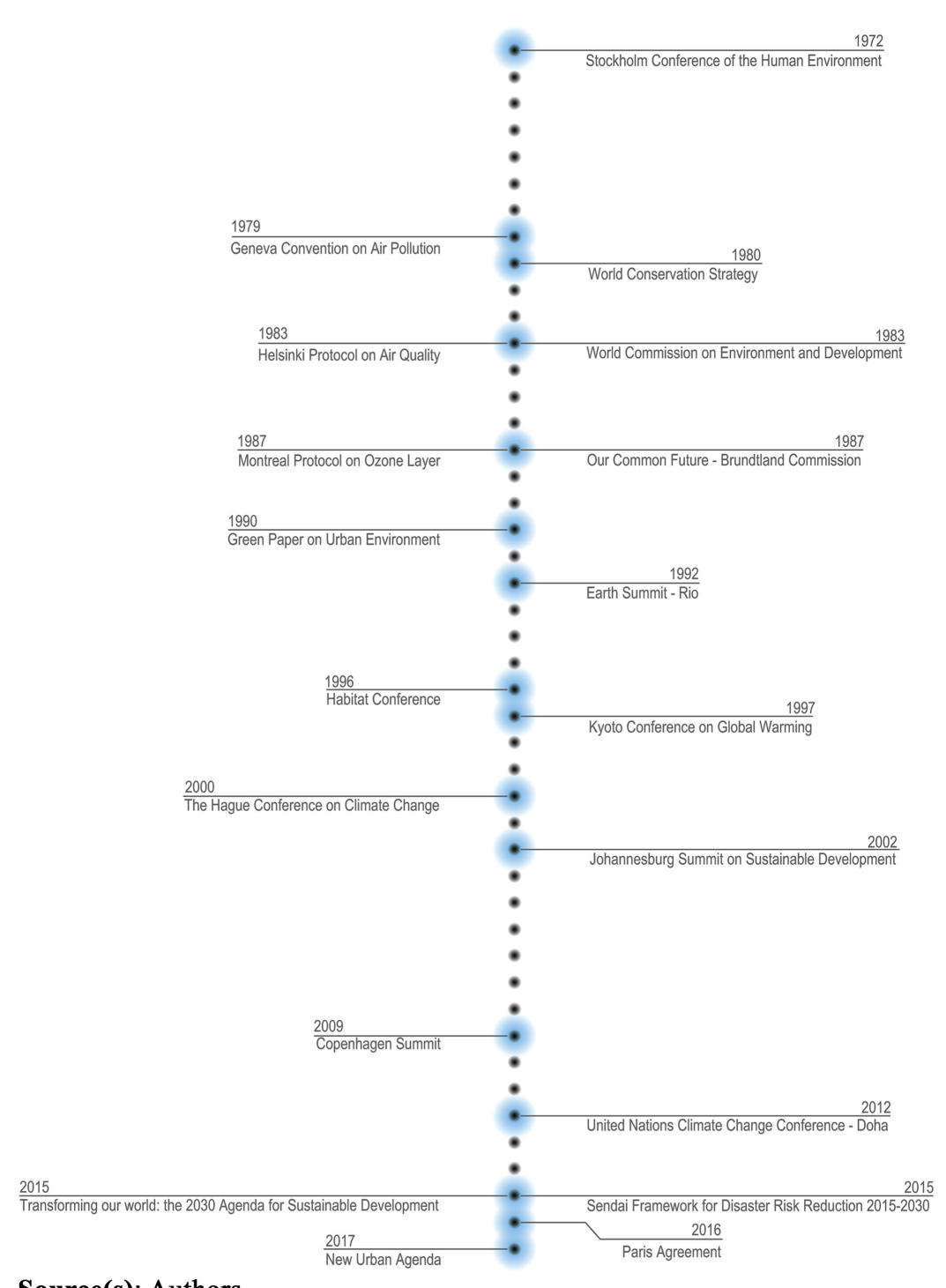

Source(s): Authors

confirms the importance of the construction industry in the sustainability discourse (Cepinha et al., 2007). Given that buildings and cities are long lived, they play a fundamental role in the realization of sustainable development (Edwards, 2005).

The link between sustainable development and the construction industry is extremely important considering the impact of this sector on all dimensions of the sustainable development. On the one hand, the benefits are seen in the enlargement of national wealth and increased number of work ranks, thus addressing economic and social sustainability aspects. On the other hand, the construction industry clearly affects greater consumption of natural 


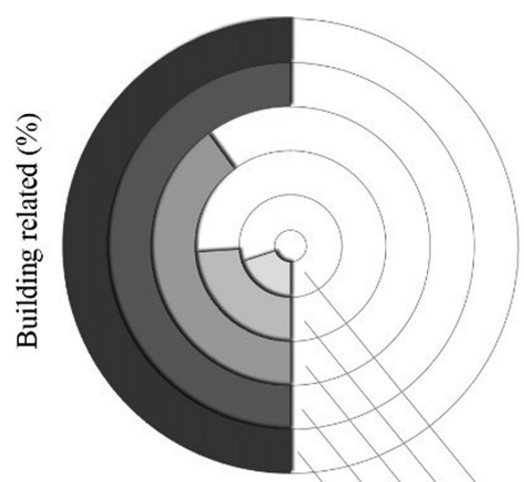

Architectural design towards climate change
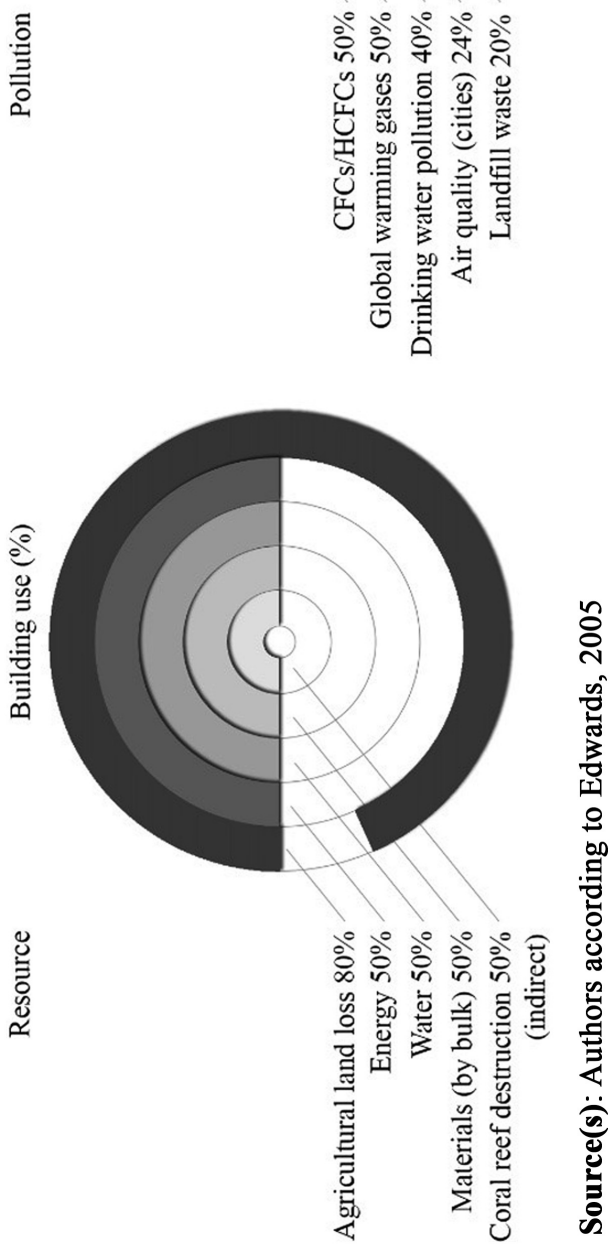

Figure 4.

Global resources used in buildings and global pollution 
resources that, consequently, raises environmental loads (Cepinha et al., 2007; Edwards, 2005; OECD, 2003). More precisely, about $50 \%$ of the natural virgin materials at the world-wide level are consumed by the construction industry that is far beyond the sustainable level. More than $40 \%$ of the produced energy is consumed in the Organisation for Economic Co-operation and Development (OECD) member countries, throughout the live cycle of the buildings, and approximately one-third of the GHG emissions are produced by the built environment. Namely, $60 \%$ of all resources globally go into construction (roads, buildings, etc.), nearly $50 \%$ of energy generated is used to heat, light and ventilate buildings and a further $3 \%$ to construct them. Further, $50 \%$ of water used globally is for sanitation and other uses in buildings; $80 \%$ of prime agricultural land, lost to farming, is used for building purposes; $60 \%$ of global timber products end up in building construction and nearly $90 \%$ of hardwoods. The environmental capital locked in buildings is enormous, as it is the waste footprint from both the construction and demolition activities, making them not only one of the most significant users of raw material but also a great waste streams producer.

The concept of sustainable construction appeared with the gradual recognition of the environmental responsibility of the construction sector. This concept was for the first time mentioned in the "First Conference on Sustainable Construction", by Charles Kibert and was defined as "the creation and responsible management of a healthy built environment based on resource efficient and ecological principles" (Cepinha et al., 2007, p. 115). According to Cepinha et al. (2007), the sustainable construction aims at fulfilling two main objectives: (1) to minimize the negative impact of the constructions on the environment and, simultaneously, (2) to create and maintain healthful environmental conditions for the users of buildings or surrounding populations to the develop project. The sustainable construction considers the materials, the ground, the energy and the water as its main resources (Cepinha et al., 2007). Kibert (2008) defines five basic principles of the sustainable construction in the following way:

(1) Reduce the consumption of resources;

(2) Reuse the resources to the maximum;

(3) Recycle materials of the end of life of the building and to use recycled resources;

(4) Protect the natural systems and its function in all the activities and

(5) Eliminate the toxic materials and by-products in all the phases of the life cycle.

The 7th Environment Action Programme (1386/2013/EU) is clear about implementing sustainability in the construction sector as a tool towards a resource-efficient, green and competitive low-carbon economy. Notably, to improve resource efficiency beyond GHG emissions and energy means to reduce the overall life cycle environmental impact of consumption.

The only way to approach sustainability in the built environment, and meet the changing needs of the users, is through informed design. According to Kincaid (2002, p. 94), physical sustainability objectives are defined in the following way: "From a physical standpoint, sustainability of the built environment is concerned with the level at which energy transformation, material extraction and ecosystem impact can be allowed to occur in perpetuity in the creation and use of buildings and infrastructure". Therefore, sustainability and sustainable design should undoubtedly be one of the guiding strategies behind all future briefs.

\section{Sustainable architectural design}

The "Declaration of Interdependence for a Sustainable Future" (IUA/AIA, 1993, para. 3) addressed the sustainable design in the following way: 
Buildings and the built environment play a major role in the human impact on the natural environment and on the quality of life; sustainable design integrates consideration of resource and energy efficiency, healthy buildings and materials, ecologically and socially sensitive land-use and an aesthetic sensitivity that inspires, affirms and ennobles; sustainable design can significantly reduce adverse human impacts on the natural environment while simultaneously improving quality of life and economic wellbeing.

The declaration laid down the principles and recommendations, stating that members of the world's architectural and building design professions, individually and through professional organizations, should commit themselves to place environmental and social sustainability at the core of our practices and professional responsibilities; develop and continually improve practices, procedures, products, curricula, services and standards that will enable the implementation of sustainable design; educate our fellow professionals, the building industry, clients, students and the general public about the critical importance and substantial opportunities of sustainable design; establish policies, regulations and practices in government and business that ensure sustainable design becomes normal practice and bring all existing and future elements of the built environment - in their design, production, use and eventual re-use - up to sustainable design standards.

In his overarching study on sustainable architectural design, De Garrido (2012) provides a variety of the goals, strategies, objectives and principles of sustainable architecture revolving around the needs of its occupants, in any time and place, without jeopardizing the welfare and development of future generations. More precisely, sustainable architecture involves strategies which aim at optimizing resources and materials; reducing energy consumption; promoting renewable energy; minimizing waste and emissions; minimizing the maintenance, functionality and cost of buildings and improving the quality of life of their occupants. The objectives that constitute the pillars upon which sustainable architecture is based are as follows: optimization of natural and artificial resources; reduction of energy consumption; promotion of natural energy sources; reduction of waste and emission; improving the quality of life for building occupants and reduction of building maintenance costs. Thus, the level of sustainability of a construction depends on the degree to which each of these objectives is attained. Furthermore, there is a list of 12 groups of generic architectural actions to be executed in order to achieve a truly sustainable architecture. Each group represents a declaration of principles of sustainable architecture and is divided into a set of directly applicable actions for the everyday design process of an architect: protecting the environment; protecting fauna and flora; ensure human nutrition; change human lifestyle and cultural values; improve human welfare and quality of life; optimize resources; promote industrialization and prefabrication; minimize emissions and waste; encourage the use of renewable natural energy; reduce energy consumption; reduce cost and maintenance and changing transport systems.

The "Whole Building Design Guide" (WBDG) established a set out rules and principles regarding sustainable design. WBDG's objectives are to (Kubba, 2012) (1) avoid resource depletion of energy, water and raw material; (2) prevent environmental degradation caused by facilities and infrastructure throughout their life cycle and (3) create liveable, comfortable, safe and productive built environments. Principles defined in the WBDG are as follows: (1) optimize site potential; (2) optimize energy use; (3) protect and conserve water; (4) use environmentally preferred products; (5) enhance indoor environmental quality and (6) optimize operations and maintenance procedures.

Edwards (2005) defines the principles of sustainable development design to be addressed at the different spatial scales, city, neighbourhood, open public space and individual building:

City level:

(1) Compaction; 

$\mathrm{ARCH}$
(2) Streets reclaimed from traffic;
(3) Increased density in suburban areas;
(4) Intensification of use where areas are well serviced by public transport (nodes and sub-nodes);
(5) Four-storey housing and
(6) Legibility.

Neighbourhood level:

(1) Diverse pattern of land uses;

(2) Safe and friendly streets;

(3) Keep historic buildings;

(4) Cycle routes; tram routes/corridors and

(5) Use local energy sources.

Open public space level:

(1) Design with nature (parks, streets, etc), biodiversity;

(2) Use derelict land/buildings first; strengthen green belts and green corridors.

Building level:

(1) Design for low environmental impact (locally, regionally and globally);

(2) Design for durability;

(3) Design for reuse;

(4) Maximize renewable energy use;

(5) Self-sheltering layouts; energy management under users' control;

(6) Design with climate;

(7) Design for health and

(8) Learn from vernacular practices.

In the contemporary architectural vocabulary, sustainable building design is frequently referred to as green design. The Leadership in Environmental and Energy Design (LEED), organization for design, operation and construction of high performance green buildings, highlights that some of the common features of green built projects are as follows: reuse an existing structure rather than build a new one; deconstruct rather than demolish, if all or part of an existing structure must be replaced; reuse materials from the old structure where possible; consider using salvaged materials from other sources; use materials made from recycled content where possible; recycle as much project waste as possible; use building materials efficiently and use energy efficiently.

According to the Office of the Federal Environmental Executive (OFEE), green building is "the practice of (1) increasing the efficiency with which buildings and their sites use energy, water and materials, and (2) reducing building impacts on human health and the environment, through better siting, design, construction, operation, maintenance, and removal-the complete building life cycle" (as cited in Fischer, 2010, p. 6). Through the green 
design and construction, out built environment would improve significantly since the buildings we build would last longer; cost less to operate; facilitate increased productivity and better working environments for workers or residents and improve the built environment so that the planet's ecosystems and communities can live a healthier and more prosperous life (Kubba, 2012). Finally, some of the primary benefits of building green include reduced energy consumption and pollution, protection of ecosystems, improved occupant health and comfort, increased productivity and reduced landfill waste (Kubba, 2012).

\subsection{Components of the sustainable architectural design}

The above mentioned definitions of sustainable architectural design prove that only parallel consideration of site, energy, materials and wastes can enable sustainable architecture. These four components constitute an overarching basis of a sustainable architectural design that goes beyond the features of an individual building to grasp the conditions of its immediate surrounding.

Site. All building activity disturbs the land which is a non-renewable resource. These disturbances should be minimized, and its use should be avoided whenever possible, thus directly leading to the biodiversity preservation (Szokolay, 2004). The use of already disturbed derelict land or the rehabilitation of neglected resources should become a key strategy in all major developments. Protection and reuse of land and sites and the need for brownfield development are powerful drivers for new approaches to sustainable city planning, while recycling of the building stock secures efficient design at the individual scale (Roaf et al., 2004; Sijakovic, 2015).

Energy. The energy conservation appears as a central concern in the quest for sustainability. Significant changes in energy system operation and interaction with occupants are needed (Domínguez-Amarillo et al., 2018). As by 2050, the world is expected to double its use of energy, one of the main points in order to achieve sustainable construction should address the improvement of the energy performance in buildings (Edwards, 2005). Thus, we first have to recognize the amount of energy used to construct the building and minimize it through good practices, as well as consider the renewable energy sources. By improving the energy performance of buildings a vast set of objectives can be reached (Cepinha et al., 2007, p. 116): (1) reduction of the global needs of energy production; (2) reduction of the emissions of carbon dioxide and consequently of GHG emissions; (3) improvement of comfort in households and workplaces; (4) contribution for cleaner cities; (5) improvement of urban regeneration; (6) improvement of the health of the population and promotion of the social inclusion and (7) increase the standards of living of the European citizens. As buildings are responsible for about $40-50 \%$ of the energy use in each member state of the EU, this makes them the main users of final energy (Cepinha et al., 2007). Furthermore, the residential sector is responsible for two-thirds and the commercial sector for one-third of the use of the energy in the buildings.

The energy in buildings is used at two levels, as Operational energy $(\mathrm{O})$, annually used for heating, cooling, ventilation, lighting and servicing the building, and Capital energy (C) or energy embodied in the materials and building processes. Regarding the latter, building materials can be divided into three broad categories: low, medium and high energy materials (Szokolay, 2004), as shown in Figure 5.

The concept of embodied energy highlights the high energy transport costs of bulky materials as stone, aggregates, brick and concrete products and the high energy processing costs of some commonly used lightweight materials like aluminium (Edwards, 2005). A number of research within building material ecology has been focused on the avoidance of known hazardous substances with negative ecological impact, and today, embodied energy is widely accepted as an evaluation parameter for the environmental sustainability of different building materials (König et al., 2010).

Material. Due to the exponential growth of the population, the search for and consumption of the materials increased to the limits of available resources (Yeang, 2001). Through the extraction, 


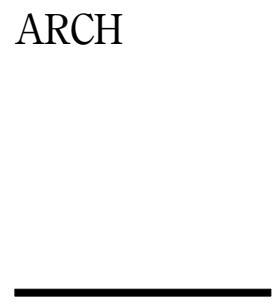

Figure 5.

Embodied energy of some building materials in $\mathrm{kWh} / \mathrm{kg}$

\begin{tabular}{lll}
\hline Low & Sand, gravel & 0.01 \\
$<1 \mathrm{kWh} / \mathrm{kg}$ & Wood & 0.1 \\
& Concrete & 0.2 \\
& Sand-lime brickwork & 0.4 \\
& Lightweight concrete & 0.5 \\
Medium & Plasterboard & 1.0 \\
$1-10 \mathrm{kWh} / \mathrm{kg}$ & Brickwork & 1.2 \\
& Lime & 1.5 \\
& Cement & 2.2 \\
& Mineral wool & 3.9 \\
& Glass & 6.0 \\
High & Porcelain & 6.1 \\
& Plastics & 10 \\
& Steel & 10 \\
& Lead & 14 \\
& Zinc & 15 \\
& Copper & 16 \\
& Aluminium & 56 \\
\hline
\end{tabular}

Source(s): Szokolay, 2004

processing, transport, use and disposal, materials used in construction industry have enormous environmental impact. Natural resources used in construction, as roads and buildings, account for about one-half of all resource consumption in the world (Edwards, 2005). Hence, not only material selection must be influenced by the embodied energy but also by a number of other issues affecting sustainability of their use (Szokolay, 2004). Embodied carbon assessment altered the way we analyse and source materials based on their carbon footprint. It considers how many greenhouse gases (GHGs) are released throughout the supply chain, including first phases of production and construction to the end of life. One of the methodologies which facilitates the selection of materials based on their environmental impact is an Environmental Product Declaration (EPD). An EPD is an independently verified and registered document, defined by International Organization for Standardization (ISO), which communicates transparent and comparable information about the life-cycle environmental impact of products. The EPD follows Life Cycle Assessment (LCA) methodology.

Waste. As towns and cities produce huge amounts of waste, including solid (refuse or trash), liquid (product of our sanitary arrangements: the discharge of baths, showers, basins, kitchen sinks and laundry tubs) and gaseous (mostly motor vehicle emissions and the discharge of power stations) wastes, architects have a strong influence on how wastes are disposed. Furthermore, the average waste produced is about $1 \mathrm{~kg} /$ pers.day in the UK, $1.5 \mathrm{~kg} /$ pers.day in Australia and up to $2.5 \mathrm{~kg} /$ pers.day in the USA (Szokolay, 2004). Collection, handling and disposal of waste are a problem given that we are running out of space for the creation of garbage dumps. Combination of cheap energy, technical sophistication and abundance has caused excessive waste, and according to some predictions, global waste production will double over the next 20 years (De Graaf, 2012).

\section{Concluding remarks}

There is a close link between the built environment and climate change. Rapid urbanization, the spread of poverty in urban areas and the fact that most people live in cities have led to the ecological crisis reflected in the climate change, pollution and decrease of non-renewable resources. 
The negative effects of the construction industry on our environment have been highlighted in this paper through the analysis of the impact of the building sector on the, rational land use, energy consumption, use of natural material and waste production. Given that $50 \%$ of the global warming gasses and $40 \%$ of the water pollution are building related, the building sector constitutes one of the biggest waste streams produced in Europe and is unquestionably the biggest polluter. Thus, it is beyond any doubt that the construction industry is one of the least sustainable industries in the world which significantly contributes to the climate change crisis.

However, the built environment offers opportunities to improve health and liveability while reducing the GHG emissions that underlie climate change. Through careful planning of systems and buildings, built environment programs can support climate change mitigation and enhance human health. The concept of sustainable building incorporates and integrates a variety of strategies during the design, construction and operation of building projects. Sustainable design principles conserve energy, protect the environment and mitigate the GHG emissions that contribute to climate change. The impact of climate change can be lessened through specific energy-saving strategies such as building site, form and material selection as well as through energy-efficient systems for heating, cooling and ventilation. Some of the key objectives, strategies and principles for sustainable architectural design observed through the lens of its main components - land, energy, material and waste - are briefly provided below.

The main objectives of the sustainable architectural design are as follows: (1) optimization of the land use; (2) reduction of energy consumption; (3) promotion of natural energy sources; (4) reuse of the building materials and (5) reduction of waste and emission. Consequently, the key strategies are as follows: (1) reusing land as a non-renewable resource; (2) reducing energy consumption; (3) promoting renewable energy; (4) optimizing resources and materials and (5) minimizing waste and emissions. Finally, the key principles of the sustainable architectural design are summarized as follows: (1) reduce the consumption of resources; (2) reuse the resources to the maximum; (3) optimize site potential; (4) diverse pattern of land uses; (5) use derelict land/buildings; (6) optimize energy use; (7) encourage the use of renewable natural energy; (8) use local energy sources; (9) recycle materials of the end of life of the building; (10) use environmentally preferred products; (11) eliminate the toxic materials and by-products in all the phases of the life cycle and (12) minimize emissions and waste.

Adaptation strategies can help prepare the built environment to better withstand the effects of climate change. By combining various built environment strategies through complimentary policies and programs, multiple co-benefits emerge. Implementation of the sustainable design strategies across scales is an important step towards reducing GHG emissions, thereby mitigating climate change effects and promoting healthier living. Therefore, an integrated design process which disregards established discipline boundaries and combines various scientific fields, including architecture, physics, engineering, climatology, physiology and psychology must be implemented in order to conceive buildings able to ensure comfort and health for their inhabitants without impacting negatively on the environment.

\section{References}

Altomonte, S. (2008), "Climate change and architecture: mitigation and adaptation strategies for a sustainable development", Journal of Sustainable Development, Vol. 1 No. 1, pp. 97-112.

Anand, S. and Sen, A. (1996), Sustainable Human Development: Concepts and Priorities, Office of Development Studies, United Nations Development Programme, New York.

Bulkeley, H. (2013), Cities and Climate Change, Routledge, Abingdon, Oxon; New York, NY. 
Castán Broto, V. (2017), "Urban governance and the politics of climate change", World Development, Vol. 93, pp. 1-15.

Cepinha, E., Ferrão, P. and Santos, S. (2007), "The certification of buildings as an enterprise strategy of the real estate sector: a national scope analysis", in Bragança, L. and Cuchí, A. (Eds), Portugal SB07. Sustainable Construction, Materials and Practices: Challenge of the Industry for the New Millennium, IOS Press, Amsterdam, pp. 113-120.

De Garrido, L. (2012), La Práctica Proyectual del Nuevo Paradigma en Arquitectura: Teoría, Diseño y Proceso Constructivo = Design Practice of the New Architectural Paradigm: Theory, Design and Construction Process, Síntesis Arquitectura, Oviedo.

De Graaf, R. (2012), "Nothing new. On the idea of recycling”, in Ciorra, P. and Marini, S. (Eds), Re-cycle: Strategies for Architecture, City and Planet, Electa S.p.A, Milano, pp. 50-63.

Domínguez-Amarillo, S., Fernandez-Aguera, J. and Fernandez-Aguera, P. (2018), "Teaching innovation and the use of social networks in architecture: learning building services design for smart and energy efficient buildings", Archnet-IIAR: International Journal of Architectural Research, Vol. 12 No. 1, pp. 367-375.

Edwards, B. (2005), Rough Guide to Sustainability, RIBA Enterprises, London.

European Commission (2007), Progress Report on the Sustainable Development Strategy, European Commission, Brussels.

Fischer, E.A. (2010), "Issues in green building and the federal response: an introduction”, International Journal of Energy, Environment and Economics, Vol. 19 No. 1, pp. 149-181.

Gauzin-Müller, D. (2002), Sustainable Architecture and Urbanism: Concepts, Technologies, Examples, Birkhäuser, Boston.

Glaser, M., Krause, G., Ratter, B. and Welp, M. (Eds), (2014), Human-Nature Interactions in the Anthropocene: Potentials of Social-Ecological Systems Analysis, Routledge, New York.

Grove, J.M., Cadenasso, M.L., Pickett, S.T.A., Machlis, G.E. and Burch, W.R. Jr (2015), The Baltimore School of Urban Ecology: Space, Scale, and Time for the Study of Cities, Yale University Press, New Haven and London.

Hughes, S., Chu, E. and Mason, S. (Eds), (2018), Climate Change in Cities: Innovations in Multi- Level Governance, Springer, Cham.

Hunt, J. (2004), "How can cities mitigate and adapt to climate change?", Building Research and Information, Vol. 32, pp. 55-57.

IPCC (Intergovernmental Panel on Climate Change) (2014a), Climate Change 2014, Impacts, Adaptation, and Vulnerability, Part A: Global and Sectoral Aspects, Working Group II Contribution to the Fifth Assessment Report of the Intergovernmental Panel on Climate Change, Cambridge University Press, Cambridge.

IPCC (Intergovernmental Panel on Climate Change) (2014b), Climate Change 2014, Synthesis Report, Contribution of Working Groups I, II and III to the Fifth Assessment Report of the Intergovernmental Panel on Climate Change, IPCC, Geneva.

IPCC (Intergovernmental Panel on Climate Change) (2018), Global Warming of $1.5^{\circ} \mathrm{C}$, World Meteorological Organization, IPCC, Geneva.

IPCC (Intergovernmental Panel on Climate Change) (2019), Climate Change and Land: An IPCC Special Report on Climate Change, Desertification, Land Degradation, Sustainable Land Management, Food Security, and Greenhouse Gas Fluxes in Terrestrial Ecosystems, IPCC, Geneva.

IUA/AIA (International Union of Architects/American Institute of Architects) (1993), "Declaration of interdependence for a sustainable future", declaration presented at the World Congress of Architects, 18-21 June, Chicago, available at: http://www.comarchitect.org/wp-content/architectsguide/declaration_ of_interdependence_for_a_sustainable_future.htm (accessed 2 May 2020).

Kibert, C. (2008), Sustainable Construction: Green Building Design and Delivery, John Wiley \& Sons, New Jersey. 
Kincaid, D. (2002), Adapting Buildings for Changing Uses: Guidelines for Change of Use Refurbishment, E \& FN Spon, London.

König, H., Kohler, N., Kreisig, J. and Lutzkendorf, T. (2010), A Life Cycle Approach to Buildings, Institut für international Architektur, Munich.

Kubba, S. (2012), Handbook of Green Building Design and Construction: LEED, BREEAM, and Green Globes, Elsevier Butterworth-Heinemann, Waltham.

LCCP (London Climate Change Partnership) (2002), London's Warming: The Impacts of Climate Change on London, Final Technical Report, Entec UK, London.

Lisø, K.R. (2001), "Effects of climate change on built environments", Cicerone, Vol. 5, pp. 1-3.

Marzluff, J.M., Shulenberger, E., Endlicher, W., Alberti, M., Bradley, G., Ryan, C., Simon, U. and ZumBrunnen, C. (Eds), (2008), Urban Ecology: An International Perspective on the Interaction between Humans and Nature, Springer, Heidelberg.

Mills, G. (2006), "Progress towards sustainable settlements: a role for urban climatology", Theoretical and Applied Climatology, Vol. 84, pp. 69-76.

OECD (Organisation for Economic Co-operation and Development) (2003), Environmentally Sustainable Buildings: Challenges and Policies, OECD Publications, Paris.

Oke, T.R. (1987), Boundary Layer Climates, Routledge, London.

Pearce, D.W., Markandya, A. and Barbier, E.B. (2007), Blueprint for a Green Economy, TPF Group, London.

Roaf, S., Horsley, R. and Gupta, R. (2004), Closing the Loop: Benchmarks for Sustainable Buildings, RIBA Publications, London.

Sijakovic, M. and Peric, A. (2014), "Recycling Architecture: the redefinition of recycling principles in the context of sustainable architectural design", in Schrenk, M., Popovich, V.V., Zeile, P. and Elisei, P. (Eds), Clever Plans for Smart Cities - Proceedings of the 19th REAL CORP 2014 International Conference, CEIT ALANOVA, Vienna, pp. 467-476.

Sijakovic, M. and Peric, A. (2018), "Symbiotic architecture: redefinition of recycling design principles", Frontiers of Architectural Research, Vol. 7, pp. 67-79.

Sijakovic, M. (2015), Recycling Industrial Architecture: The Redefinition of Recycling Principles in the Context of Sustainable Urban Regeneration (Doctoral Dissertation), Universitat Politecnica de Catalunya, BarcelonaTech, Barcelona.

Souch, C. and Grimmond, S. (2006), "Applied climatology: urban climate", Progress in Physical Geography, Vol. 30, pp. 270-279.

Steffen, W., Broadgate, W., DeutschGaffney, L.O. and Ludwig, C. (2015), "The trajectory of the anthropocene: the great acceleration", The Anthropocene Review, Vol. 2 No. 1, pp. 81-98.

Szokolay, S.V. (2004), Introduction to Architectural Science: The Basis of Sustainable Design, Architectural Press, Oxford.

UN DESA (United Nations Department of Economic and Social Affairs) (2019), "UN DESA world population prospects", available at: https:/ec.europa.eu/knowledge4policy/dataset/ds00070_en (accessed 15 June 2020).

UN (United Nations) (2015), Transforming Our World: The 2030 Agenda for Sustainable Development, A/RES/70/1, available at: https://sustainabledevelopment.un.org/content/documents/ 21252030\%20Agenda\%20for\%20Sustainable\%20Development\% (accessed 10 May 2020).

UN (United Nations) (2017), New Urban Agenda, Habitat III Secretariat, Ecuador.

UNFCCC (United Nations Framework Convention on Climate Change) (2015), Paris Agreement, FCCC/ CP/2015/L.9/Rev.1, Paris.

UN-Habitat (2016), Addressing Climate Change in National Urban Policy: A Policy Guide for LowCarbon and Climate-Resilient Urban Development, UN-Habitat, Nairobi. 
UN-Habitat (2017), Sustainable Urbanization in the Paris Agreement: Comparative Review for Urban Content in the Nationally Determined Contributions (NDCs), UN-Habitat, Nairobi.

UNISDR (United Nations Office for Disaster Risk Reduction) (2015), Sendai Framework for Disaster Risk Reduction 2015-2030, UNISDR, Geneva.

WACOSS (Western Australia Council of Social Services) (2008), Model of Social Sustainability, WACOSS, West Perth.

WCED (World Commission on Environment and Development) (1987), Our Common Future Brundtland Report, Oxford University Press, Oxford.

Wilby, R.L. (2007), "A review of climate change impacts on the built environment”, Built Environment, Vol. 33 No. 1, pp. 31-45.

Wolfram, M., van der Heijden, J., Juhola, S. and Patterson, J. (2019), "Learning in urban climate governance: concepts, key issues and challenges", Journal of Environmental Policy and Planning, Vol. 21 No. 1, pp. 1-15.

Yeang, K. (2001), El Rascacielos Ecológico, Gustavo Gili, Barcelona.

Younger, M., Morrow-Almeida, H.R., Vindigni, S.M. and Dannenberg, A.L. (2008), "The built environment, climate change, and health: opportunities for co-benefits", American Journal of Preventive Medicine, Vol. 35 No. 5, pp. 517-526.

\title{
Further reading
}

CIB (International Council for Research and Innovation in Building and Construction) (1999), Agenda 21 on Sustainable Construction, CIB Report Publication, Rotterdam.

Decision 1386/2013/EU of the European Parliament and of the Council of 20 November 2013 on a General Union Environment Action Programme to (2020), "Living well, within the limits of our planet”, Official Journal of the European Union, Vol. 354, pp. 171-200, 28.12.2013.

Graves, H.M. and Philipson, M.C. (2000), Potential Implications of Climate Change in the Built Environment, Building Research Establishment (BRE)/Foundation for the Built Environment (FBE), Watford.

Lawson, B. (1996), Building Materials, Energy and the Environment, RAIA, Canberra.

\begin{abstract}
About the authors
Milan Sijakovic received his March degree at the Faculty of Architecture, University of Belgrade. Furthermore, he obtained Master's degree in Theory and Practice of Architectural Design and a PhD Cum Laude title from the BarcelonaTech, UPC, Spain. His research interests are directed towards the fields of sustainable design and architectural recycling, with particular focus on industrial heritage and the possibility of its sustainable revitalization. Besides his academic achievements, he has a considerable experience in the architectural and urban design practice, obtained through the work within the City of Barcelona, Department of Infrastructure and Urban Planning. Milan Sijakovic is the corresponding author and can be contacted at: milansijakovic@gmail.com

Ana Peric holds a PhD in Urban Planning from the University of Belgrade and is engaged as Lecturer at ETH Zurich as well as Research Fellow at the University of Belgrade. Her research interests include collaborative urban planning, planning cultures and territorial governance. In her research, she examines the relationship between the underlying contextual factors and the nature of planning processes with specific focus on collaborative and participatory planning instruments, methods and theory. She is the Board Member of ISOCARP (International Society of City and Regional Planners) and the member of AESOP's (Association of European Schools of Planning) Quality Recognition Working Group.
\end{abstract}

For instructions on how to order reprints of this article, please visit our website:

www.emeraldgrouppublishing.com/licensing/reprints.htm

Or contact us for further details: permissions@emeraldinsight.com 